\title{
Substitution or complementarity between "soft" information and "hard" information: why and which effect on bank profitability?
}

\author{
Hervé Alexandre* \\ Aymen Smondel $^{* *}$ \\ Université Paris-Dauphine \\ DRM F \\ 75016 Paris, France \\ Janvier 2010
}

\begin{abstract}
The Basel II committee set up directives encouraging banks to use internal scores in order to assess the risk of their customers. This new form of information competes with the existing ones. SMEs are most concerned by these new stakes, due to the lack of transparency.

The aim of this paper is to understand the determinants of the choice between substitution and complementarity between the two types of information: "soft" and "hard", to test a potential effect of this choice on the banking performance and to describe which variables are involved in the decision-making process.

The originality of this work is to try to quantify the information costs and to use it as a variable which is affecting the adopted choice.
\end{abstract}

JEL Classification: G21, G24, G39

Keywords: Basel directives, "soft" information, "hard" information, credit decision-making process, bank performance, Bank-SMEs relationship.

\footnotetext{
*E-mail : Herve.ALEXANDRE@ dauphine.fr

** E-mail : smondelaymen@gmail.com
} 


\section{Introduction}

The most known activity of the bank is collecting funds from depositaries and allotting credits to borrowers. This financial intermediation contains several risks which are primarily related to not respecting the engagements or the insolvency of borrowers. To face these risks, banks set up and developed tools to evaluate, to measure and to control them.

The upheavals of the banking sector which result from the bankruptcies of banks, such us the incident of the German bank: "Herstott", which generated domino effect in this sector and leaded to a serious financial crisis. This situation encouraged the "group of ten's" central banks governors to set up an institution of control in order to stimulate the co-operation and to promote the international harmonization of banking prudential monitoring: the committee of Basle. In spite of the fact that this institution does not have any authority and that its conclusions do not have the force of law, its directives widely affected the banking activity. The most famous achievements of the Committee are the first and the second agreement of Basle (Basle I \& Basle II), which propose the unification of risk management and the implementation of modelling processes.

This modelling evokes necessarily the treatment of "hard" information in opposition to those already used and which are based on the "soft" information. Thus, in order to rigorously respect the directives of Basle, researchers are divided into two groups: the first workshop supported the substitution of "soft" information by "hard" information, but, the second one stand up for the complementarity between the two types of information.

Indeed, in the first case, banks can replace the actual decision process by another one which is based exclusively on financial and accounting data. This is argued not only by the strict standardization of risk measurements, but also by the unification of the evaluation methods. Alternatively, the complementarities between the two types of information can be choose in order to take profit from "soft" information advantages in the same time of integrating the new procedures.

The principal question is to know what the variables that determine the adopted banks choice are.

The attributed scores are calculated within banks according to characteristics and specificities suitable for each one of them. This is why a differential exists between the decision-making processes according to the chosen loan request treatment strategy. 
These changes are not assigned to all borrowers at the same degree: SMEs remain the most vulnerable customers. In fact, the access of this segment of customers to the credit is increasingly restrictive whereas the request is rising. This is the result of the fact that a personalized treatment must be implemented to respond to their informational characters: their bad financial data quality and their opacity.

Our work will be particularly focussed on this segment of customers which constitute the major issues of the Basle Committee directives application.

The great differences between banks prevent the generalization of the Basle II directives. Each bank characteristics and each country banking system constitute an important constraint in the choice of adequate information for the treatment of the loan request.

The differential noted in the loan demand treatment can lead us to think that these informational and functional level transformations do not remain without consequences on the banks performance, but what about the significativity of these consequences?

To answer these two questions, it will be necessary to divide this paper into three parts.

In the first one, we will present an empirical measurement of the statistical significativity of the variables which explain the banks choices concerning the information treatment: substitution or complementarity. In the second part, we will test the significativity of the impact of this choice on banks performance and in the third part we will give a statistical description of the decision-making process of the loan officer. This last part will show the importance of the loan technology adequacy with the characteristics of credit scheme.

The plan of this study will be as follows. The first section will present the review of the literature and the various assumptions, the second section will give a description of the data and variables, the third section will present methodology and the results of the regressions, finally the last section will conclude my work.

\section{Theories and assumptions}

The excessive risk taking, adopted by the financial institutions, threatens the financial system and amplifies its weakness. In order to predict and reduce this threat, the Basle committee recommended the harmonization of the measurement models by imposing at banks the use of the internal scores, which are essentially based on "hard" information and consequently allow a best credits monitoring.

The installation of the reliable control systems leading to standardization of the methods of control contributes to the stability of the world banking system. However, the generalization 
of these systems has an important constraint. In fact, differences between international financial systems and the bank's roles amplify the difficulties to extend this system of control. Moreover, not only the divergence between banks affects the choice of adequate information but also their compatibility with the two types of information do.

\section{1. "Soft" information vs "hard" information}

"Soft" information is qualitative data, reduced to a written text which represents the judgments and the opinions of the person who collected it. This information is collected and used by the same person who is supposed having tight and direct relationship with SMEs. This relationship must be established with the low hierarchical levels of the bank.

"Hard" information is a quantitative data, impersonal and independent of the context of its collect. It presents neither a judgment, nor an opinion, but only an interpretation done by the officer who collects it. He hasn't any power of decision and any latitude, during the use of this type of information: he becomes a simple reporter (Stein, 2002). "Hard" information is based on relatively objective criteria, like the financial ratios and the indices of profitability. It must have a single interpretation by all agents of all hierarchical levels of the bank. This impersonal information is opposed to "soft" information.

The fundamental difference between these two types of information will generate an important divergence on their roles in the decision process and credit monitoring.

Costs generated by each type of information are the main issue of their installation. Costs of information consist on research, verification and control costs (Godlewski, 2004). But we can suppose that they can include the collection, treatment and storage costs.

Stein (2002) supposes that the loan officers, during the use of "hard" information in the decision process, are transformed into simple reporters. Indeed, the collection and the treatment of "hard" information do not require important qualifications, contrary to "soft" information which requires agents highly qualified. The necessary qualifications, needed for the "soft" information analysis, force banks to recruit agents more experienced and more competent and to pay high wages. By adopting "hard" information, banks may reduce personal payment. As a matter of fact, the centralization of the decision, resulting from the use of "hard" information, improve a concentration of competences on high hierarchical levels within which decision are taken and consequently a less of qualifications on low hierarchical levels. Still, this centralization requires a better transmission of information.

"Hard" information is characterized by its easy transmission and storage; this requires only low costs computer tools. The quality of these supports and their great life length contributed to the proliferation of this kind of information. 
Contrary to the latter, the "soft" information is a personal judgment and a subjective opinion of the person who collects and treats it. This loan officer will generate additional costs affecting the bank profitability. According to, Berger, Frame \& Miller (2005) and Berger \& Deyoung (2000), scores that are essentially based on "hard" information, allow the reduction of the loan officer control costs and more generally the reduction of governance costs.

This costs decrease enables banks to offer marginal credit which generated not enough interests to cover the high "soft" information treatment expenses. The "hard" information eliminates the effect of distance as well as the associated availability and control difficulties. (Deyoung \& Al, 2008).

Loans Technologies represent the system set up by banks to study the requests of credits. According to Udell (2008), technologies of loan are dependant on the nature of information used. There exist two big classes of technologies, according to the nature of information used: the relationship Bank-SMEs based on "soft" information and the technologies based on transactions using "hard" information. (Stein 2002, Stick Goldberg \& White 2004, Frame \& Al, 2001, Berger \& Al 2005).

In theory, the exploitation of the relationship Bank-SMEs proved the best technology of loan. It minimizes the problems of information asymmetry but, it presents major difficulties for the loan officer to re-transcribe his opinion and his judgment and to extract reliable information for the decision.

For SMEs, banks are always the most important source of finance (Berger \& Udell, 1996). The optimal management of the loan request, on this segment of customers, depends crucially on the adaptation of the technology of loan to the specific requirements of this category of firms. SMEs privilege the durable relationship with their banks in order to balance out their opacity. Relationship Bank-SMEs is still associated with a decision process different from that based on "hard" information. (Berger \& Udell, 2002).

\subsubsection{Relationship Bank-SMEs and the reduce of information asymmetry problems}

Berger \& Udell (2002) were interested in problems of agency. They qualify the bank as chain of relationships of agency between borrowers, credit officers, directors, shareholders, depositaries and government regulators.

In this chain, we will be interested particularly in the links connecting borrowers to credit officers, at first, and credit officers to directors, at second.

The credit officer is all the time trying to avoid two problems that were presented for the first time by Stiglitz \& Weiss (1981). They fear not detect the real risk of project and thus under 
remunerate the risk taken by the bank: it is the adverse selection, or not react vis-à-vis embezzlement for another project, it is the hazard moral (Berger \& Udell, 2002).

In this first relationship of agency, the nature of information plays a crucial role in the credit control. The collected "soft" information throughout the time is more complete so it can reduce the risk of information asymmetry. Stick (1998) confirms this idea by specifying that SMEs feel in a friendly relationship with banks, maintaining a lending relationship based on "soft" information. The lending relationship is one of the most effective means to reduce the problem of information and is still an important mean to determine the terms of credit contract (Berger \& Udell, 2002). Godbillon-Camus \& Godlewski (2006) assure that "soft" information reduces the problems of hazard moral and adverse selection by decreasing the problems of discretion. Contrary to "hard" information which refers to mathematical data and financial ratios and which are based primarily on financial documents presented by SMEs. However, those can rig the results and doctor the accounts, hide reality, in order to obtain a credit.

"Soft" information is more adequate to resolve the informational problems between lenders and borrowers. But the accumulation of this type of information can give more liberty to credit officer and generate new problems of agency tied to the control of the officer scope during the granting of the credit. The asymmetry of information between the credit officers and their superiors generates problems of confidence and difficulties to optimize funds allocation. The accumulation of "soft" information can harm the control done by the directors.

The short-term vision of the credit officers can also generate agency problems (Berger \& Udell, 2002). Indeed, the system of remuneration of these agents which is indexed on the generated profits of the granted credits, privileges offering credit at court term and a personal relationship or a will to dissimulate realities supporting the retention of information.

Within a small commune, the proximity and its positioning in the local economic life lead the credit officers to enrich, to improve and to personalize the relationship with the firm. This complex interrelationship leads to a climate of solidarity and unity between all of the different actors. The delimitation between personal and professional relationship push the credit officer to feel to belong to this community, and he feels an attachment or reciprocity towards the manager of the firm. Berger \& Udell (2002) argue this idea by the study of Uzzi \& Gillespie (1999) in which they used a sociological paradigm to frame the relationship in the terms of social attachment towards the owner of the firm. Furthermore, Godlewski (2004) showed the benefit of decision decentralization and the information treatment using the study of Liberti (2004), who take an empirical study on the decentralization of authority and its impact on the 
effort of the loan officer. They used the theoretical framework of Aghion \& Tirole (1997) to study foreign banks in Argentina. Their results showed that officers who receive more authority use more efficiently their "soft" information. Indeed, credit officer holding a higher decisional power can be emphasized and feels more responsible of his decisions. He tries to always take the best decision because he feels the only responsible in front of his superiors. Nevertheless, he will not feel responsible for these decisions in case of not being the maker of them. If he feels like a simple reporter who collects information and transmits them to his directors who make the decision, he'll not provide the same effort nor will he have the same motivation.

Berger \& Udell (2002) support this close relationship between the nature of information and control. They specify that each technology of loan consists of a combination between the primary information source, mechanisms and procedures of monitoring. For this reason the procedure of decision making defers along different banks and also along different countries. The use of "soft" information requires a treatment of personalized credit and it is based on proximity to the firm decision maker.

Bankers are social members, so they are sensitive to their environment and made change their decisions and behaviours according to the circumstances. An economic recession or a financial crisis can influence the agent judgment. "Soft" information is collected over one rather long period and consequently it is possible to differentiate between the borrower failures and the economic crises and their effects on his activity. Information that is collected from customers, suppliers and the owner of the firm can concern the general environment in which the firm operates (Berger \& Udell, 2002). The check and the quality control of the very subjective "soft" information remain difficult to realize. On contrary, "hard" information cannot integrate economic factors and specificities of its collect. "Hard" information depends neither to the context nor to the geographical and temporal limits of the collection (Godlewski, 2004).

The role of the loan officer appears simple but information collect is not monotonous throughout the period. The officer must provide extra efforts to be able to take account of the changes which affect the determinants of the relationship. There are three determinants of the relationship between the bank and the borrower: characteristics of the bank, characteristics of the borrower and characteristics of the market.

We can find other variables influencing the relationship and not depending on these determinants. These are presented by Deyoung, Glennon \& Nigro (2008) as follows: the 
quality of collected information, the services offered to the customer and the cost generated by the production of information.

The information which is collected during the credit relationship concerns the firm, its owner and the global economic environment in which she exerts. The strength of this relationship affects costs and availability of credits and; it is measured by the LENGTH and the total lent amount, (Berger \& Udell, 2002). Udell (2008) gave other indices to measure the strength of the relationship: his breadth and the inverse of the number of banks.

The length of the relationship is regarded as one of the most important indicators of the force of the relationship and it can affect the prices of the credits and their availability. Indeed, relationship length variation affects interest rate, the availability and even the terms of credit. The variation of the prices along the time is still an unsolved subject of discussion. At first, we can envisage a fall of the prices in time, by the fact that the quantity of information collected over the period is accrued and thus gives a better visibility of the firm that will profit from more interesting prices compared to other firms. Secondly, we can support the idea of Elsas (2005) which states that information collection is not monotonous; the flow of private information collected from relationship can be reduced or give negative signs, it can discredit preceding information, which generates a rising of prices instead of a decreasing of them.

The measurement of the relationship breadth is based primarily on the amounts granted by the bank to its customer. A bank can grant important sums to only one firm which maintains a strong relationship with the bank. The amounts granted by the bank reassure the other financial institutions. The relationship with the bank is a certificate for the good health of the firm.

If the bank offers services to its customers, apart credit, the volume of these services can indicate the relationship strength. Indeed, one bank offering several services to a firm has more contact with this one. The services offered by the bank and touching the financial aspect give him an excellent visibility on the financial "health" of the firm.

The bank can change behaviour between one customer and the others according to the history of its relationship and can impose clauses or terms of contracts more or less restrictive according to the customer. The importance of this clauses and terms can explain the strength of the relationship and the power of the bank in it. The bank misusing of power of negotiation can go until a strategy of "holding" by which it dominates SMEs and imposes its conditions and its preferences to them. Face to this strategy, SMEs tries to diversify their funding sources 
and generates more discretion and opacity, and consequently, the bank loses its advantage compared to other establishments ${ }^{1}$. Cole (1998) shows that banks don't privilege offering credit to the firms having multiple funding sources because of the difficulties to obtain private information. Foglia, Laviola \& Maruello (1998) approve again this idea by noting that the relationship with only one bank gives an atmosphere of confidence and consolidates the relationship in time.

SMEs suffer from a shortage of financing that could be generated mainly by their asymmetry of information. During their first business year, they use internal sources of financing. The relationship between banks and firms can play a key part in the resolution of the problems of information asymmetry and soften the imperfections of the financial market, (Berger \& al, 2008). Indeed this relationship gives the possibility to banks to intervene in the management of their customers at the time of a crisis and/or a risk of insolvency.

We should specify that there exist two situations distinct from loan demand.

A first loan application:

- When the request is made, the bank does not have an advantage compared to the other financial institutions, (Lummer \& Mc Connel, 1989; Elyasiani \& Goldberg, 2004). These last authors add that it is only after a period of time that banks produces information and profits from the relationship. They stress on the time, by specifying that the length of relationship has positive effects on its' advantages.

A request following an existing relationship:

- Contrary to the first situation, the bank exploits this proximity to optimize its decisions and to avoid any kind of informational deformation. Elyasiani \& Goldberg (2004) as Boot (2000) support the idea that the relationship between the lender and the borrower can produce an important informational input helping the lender to take the decision of credit supply, to evaluate borrower and to determine credit specificities and terms.

HYP 1: The nature of used information defers between a first loan request and a "post relationship" request.

We supposed that historically, the bank must produce information beyond public information because it is crucial for the decision of credit and stay an important indicator of the customer solvency. The bank profits from its proximity relationship with SMEs to solve the problem of asymmetry of information. Compared to the other financial institutions, it can be engaged in specific contracts releasing advantages. Banks having a considerable weight on the market

\footnotetext{
${ }^{1}$ For more details, this idea was quite detailed in the paper of Cole (1998).
} 
can be allowed to choose good borrowers, (Petersen \& Rajan, 1995). Good borrowers are the least risky and thus most resistant in front of the environment changes. The advantage of choosing good borrowers or less risky allows to solve the problem of informational opacity (Cole, 1998).

SMEs feel financial security in a relationship with the small banks which have a low organizational hierarchy. They profit from a relationship and more agents availability for a personalized monitoring of their request. SMEs are more transparent with their bank and situation allows an increase of information flows. It seems obvious that more information could generate less ambiguity. This organization supports a greater transparency and a better transmission of information.

The relationship is one of the most effective means to reduce the asymmetry of information. It affects the decision and determines the terms of credit (Berger, 2002). Banks are not satisfied any more by any kind of information but they require relevant information for decision and to fix terms of credit. The credit terms vary with the mass of "soft" information. The absence of exact information pushes the banks to adopt an adverse selection of SMEs, (Godbillon-Camus \& Godlewski, 2006).

Elements that can change the relationship are, chiefly: technological development, the change of regulations, the competition conditions and the macroeconomics, (Berger \& Udell, 2002). Thus, all these variables can influence the relationship existing between banks and their borrowers and can push the former to substitute this relationship by other technologies more adapted to new requirements.

HYP 2: The contact between the credit officer and SMEs promote the information "soft" transfer.

\subsubsection{The technology of loan based on a transaction.}

According to Berger \& Al (2005), technologies for the credit decision-making are essentially based on financial and assets statements, ratings or the personal relationship ${ }^{2}$. Technologies of transaction are based on "hard" information. They vary according to the information sources, firm characteristics, the regulation changes and the nature of the used data.

The credit decision, which is based on the financial statements, requires them to be reliable (Berger \& Udell, 1998). This reliability is generally related to the transparency of the firm. The technology of loan based on the data of the financial statements is more adapted for the

\footnotetext{
${ }^{2}$ This classification was more detailed by Berger \& Udell (2002)
} 
relatively transparent firms (Berger \& Udell, 2002). This transparency is positively related to the firm size. A large company must hold correct financial statements. This transparency is the answer to the need for transmission of relevant information to the bank. Thus the technology of credit decision based on the financial statements is destined especially for the big firms characterized by the rigor of their financial data.

The assets statements give a more precise idea on the value of the guarantees and the mortgages which a firm can present for a credit. The technology which is based on the assets statement evokes the problem of the mortgage evaluation, because this evaluation is subjective. The credit officer who works within the bank can estimate a wrong value of the mortgages. To avoid this problem, banks are interested especially in new acquisitions or they will have recourse to experts who will determine with exactitude the value of the mortgage.

As firms become bigger and older as its banking financial access is easy. This idea is based on the fact that older and larger firms have more assets to present like guarantee and to reduce informational opacity (Vos \& Al, 2007). But, Udell (2008) is opposed to this idea and he specifies that the technology based on the assets is mainly subscribed on the basis of mortgage and thus the general opacity of the firm is relatively inconsistent.

Use of scores is limited to the mature economies, in which the borrower's databases and the rating offices are developed, (Udell, 2008). The recourse to scores is explained by a development of amount and number of credit (Berger, Frame \& Miller 2005 and Cater \& Mc Nulty 2005). The credit officer does not manage any more the big number of the loan requests by collecting and treating the "soft" information but, in place, he have recourse to scores to benefit from the existing financial information: easy to treat and control. The use of the scores for SMEs credits is one of the most important innovations in the financial services, (Berger \& $\mathrm{Al}, 2001)$.

We can find two kinds of scores: internal scores and external scores. The internal scores are calculated by the bank, whereas the external scores are obtained from the rating offices or other financial institutions. Banks which use the scores are divided into two parts according to the type of the used scores. Those using the external scores adhere to "rules" whereas those which develop their internal scores adhere to "discretion" (Berger, Frame \& Miller, 2005).

Banks which use the external scores try to be aligned to other establishments and do not benefit from the flexibility of the internal scores. They seek using the same public information and the same rules of the market. These banks are not interested by the specificities of their customers. Contrary, banks which adhere to discretion benefit from internal scores which are 
adapted to bank characteristics and borrowers specificities. All collected information and scores are confidential and stay the exclusive property of the bank.

The use of the scores can be accompanied by another detailed study relating to the borrower if he obtains a score near to the threshold value (Godlowski, 2004). The use of the scores does not prove that the bank has best valorisations or the most exact information about borrowers and does not guarantee that the bank took the good decision but that it reduces its' costs, accelerates and improves the decision making (Deyoung, Lennon \& Nigro, 2008). The market requires more reactivity, so banks must reduce the response time to the loan request and optimize their treatment. To answer this time constraint the bankers adopt information that is easier to collect and to treat.

\section{HYP 3: the time constraint of the request treatment favours the use of only "hard"} information.

External scores are generally calculated in rating offices and thereafter sold to the banks. The low costs of these scores can be the key motivation for their adoption and their use to decide of the credit supply (Berger \& Frame 2005). The use of these scores generates a greater competitiveness on the banking market. The scores used by banks are considered as public data accessible by everyone. The external scores are standardized and do not privilege the banks which use them. The slicing character of the use of scores leads to rigidity in making decisions and aggravates the problem of firm opacity (Berger \& Frame 2005).

The use of the internal scores exists since a long time yet but the committee of Basle directives contributed to their generalization. The committee of Basle incited banks to calculate the internal scores specific to their characteristics. The processes, which allow banks to calculate internal scores, can solve the problem of the exaggeration of risk taking but they can create at the same time a new problem of agency (Berger \& Udell 2002). In fact, the internal scores generated new conflicts between banks and the banking market supervisors. Regulators, who are charged to monitor banking intermediation on the credit market and applying the Basle committee directives, cannot determine all specificities of banks and are unable to control their risk taking (Fees \& Hege 2004).

Up to now, banks stay rigid in the studies of the requests of credit. Only the informational character is important, the size of the credit was neglected. Godlewski (2004) stipulated that credit problems come from the ex ante information imperfection regarding the risk of failure of the potential borrowers. However, the approach presented by Keeton (1979) was described 
as appealing by Lobez (1988) because it is founded on non homogeneity of the credit. The decomposition of the credit leads us to wonder if their size influences the decision of supply.

The integration of the influence of the credit amount in decision making is a result of the enforcement of the Basle agreements. Banks must fix the capital to be lent at the beginning of every year to preserve the regulation ratios. The application of models based on the scores reduces the quality of collected information. Large credits tend to be more exacting in terms of information because they weigh heavier on the risk.

Information treatment cost in decision making which can be take into account by the banks; the more important the amount of credit is, the less significant the costs of information are, which supports thorough searches for information. Lobez (1988) gives the following example: lending hundred Euros thousand times does not generate the same costs for the bank as to lend thousand Euros hundred times. Furthermore, banks support the use of less expensive information if they judge that the requested credit amounts are not important. Berger \& Frame (2005) specify that the growth, of the availability of credits for SMEs, is rather due to the reduction in the costs of implementation of scores that reduction in opacity. Small credits tend to have their prices being more raised than largest in order to cover the costs of the information treatment.

HYP 4: The average credit amount is positively correlated with the use of "hard" information.

\subsection{The nature of information and bank characteristics}

Banking sector was divided into two main categories: small banks and large banks ${ }^{3}$. The small banks have recourse to "soft" information whereas large banks use "hard" information (Berger \& Al 1998, Berger \& Al 2002, Stick \& Al 2004, Petersen 2004, Petersen \& Rajan, 2002 and Stein 2002). The specialization of the small banks in "soft" information and the large ones in "hard" information answers to the specific needs of each one. The large banks tend to standardize their procedures and to decentralize their decisions, thus, they need information easy to verify and control.

Large banks are better in the markets characterized by standardized credit and not personalized services (Carter \& Mc Nulty 2005). Standardized products do require neither a particular treatment nor a specific collection of information. "Hard" information can be sufficient for such technology of loan. By using this category of information, large banks

\footnotetext{
${ }^{3}$ Stein (2002) is the source of this partition.
} 
penalize small borrowers, who privilege a durable relationship for the access to the credit. Large banks tend to reduce their credits to SMEs and to use the financial ratios more than the information emitted during the established relationship (Berger \& Udell 2002). Indeed, according to Berger, Frame \& Miller, (2005) the bank size is negatively correlated with the volume of the credits devoted to SMEs.

Large banks are more competitive than small ones in the supply of credits to distant customers. Small banks are adapted to maintain a durable relationship with these customers (Deyoung, Lenon \& Nigro 2008 and Berger \& Al 2005). This durable relationship involves the collection of "soft" information and depends especially on competences of small banks which benefit from this situation of proximity by positioning on niches of customers forsaken by largest. By using "soft" information, small banks are more competitive than large ones in the supply of small credits (Carter \& Mc Nulty 2005, Berger \& Al 2002). The need for a durable and personalized relationship with SMEs can ensure the survival of the small banks community, (Udell 2008, Deyoung, Hunter \& Udell 2004).

\section{HYP 5: Large banks are encouraged by their size to adopt "hard" information.}

The organisational structure is generally related to the size of the bank whereas the organisational complexity can be observed in a small bank and/or not to in large ones. Banks can adopt behaviours which do not reflect their sizes. A small bank which belongs to "hold up" cannot behave like such and must follow the instructions of this dominating firm (Keeton, 1995; Carter \& Mc Nulty 2005).

Organisational complexity is of two types: horizontal complexity related to the diversity of bank functions and vertical complexity related to the number of the hierarchical levels (Frame, Srinivasan \& Woosley 2001). Berger \& Frame (2005) evoke the idea that the organisational structure of the bank plays an important role in the choice of information needed for making decisions: it is preferable for the banks which have few charters and more branches of activity to adopt the scores based mainly on "hard" information. These authors base their argument on other studies such as Frame, Srinivisan \& woosley (2001) and of Akhavian, Frame \& White (2005). The banks' complex organization encourages them to use information easy to transmit and to verify during time and/or between various agents.

Small banks that with restricted hierarchical levels use "soft" information to face the information asymmetry problems (Berger \& Udell 2002). The esteem and gratitude given to the work of the credit officer by the manager of the decentralized institutions optimize the information use (Liberti 2004). The transmission and the reliability of "soft" information are more important in the decentralized organizations (Godlowski 2004). 


\section{HYP 6: Banks which decentralize the decision of credit use "soft" information.}

During the treatment of credit request, banks can be devoted to two variables: the cost and the quality of treated information. Banks do not adopt the same strategic choice and do not make the same arbitration between the cost and the quality of information. Berger, Frame \& Miller (2005) support the idea that the scores are adopted to minimize the costs or to increase the precision ${ }^{4}$. They add that we can distinguish two types of banks: those using the external scores to decide and those using them like a complement with technology in place to improve the precision of decision.

Banks that are seeking to minimize the costs of collection and of treatment of information necessary to the credit decision adopt "hard" information. Deyoung, Lennon \& Nigro (2008) present two manners of reducing the costs during the use of "hard" information. The reduction can be the result of its low costs of treatment in opposition to "soft" information or the neutralization of the effect of distances, which follows from the treatment of "hard" information

The minimization of costs can be the motivation of the adoption of scores and their use for the credit decision-making but it can also aggravate firm opacity problems and the contract clauses (Berger \& Frame 2005).

HYP 7: the cost of collection, treatment and storage of information explains the nature of information used; the high cost explains the use of "soft" information.

"Hard" Information is certainly less expensive but it is based mainly on financial and accounting data. But "soft" information is more complete and better reflects the real situation of the firm. It integrates general data on the leader, economic environment and on various variables affecting the firm activity: thus, it's richer than "hard" information. The complementarity between these two types of information makes it possible to the bank to make a more relevant decision. By doing this way, they minimize losses related to the bad attribution of the credits. After having eliminated bad borrowers, banks will be able to reduce the provisions for loan losses and to benefit from a less risky situation. The motivation of few banks is to improve the precision of the decision, which leads as the importance of combined use of "hard" information and "soft" information. This idea was treated in several studies

\footnotetext{
${ }^{4}$ The scores is a form of "hard" information in its strict sense and which we can generalize for all other forms of information "hard".
} 
such as Deyoung, Lenon \& Nigro (2008), Frame, Srinivasan \& Woosley (1998) and Akhavein, Frame \& White (2005).

\section{HYP 8: The complementarity between the two types of information is negatively related to the risk level of bank.}

The information used by the bank can affect its total activity. If the bank adopts the combination of the two types of information, it can improve its capacity to anticipate the failures and consequently, ameliorate its performance.

By deduction, one can explain the link between the bank performance and its strategy of loan request management: by using the two types of information, banks obtain a better visibility on their customers and more relevant decisions. This leads to a reduction of both credit losses and credit risk. This reduction contributes to a better attribution of the bank capital and the reduction of the reserve fixed by the directives of Basle. By respecting the legal ratios, banks benefit from the sinking of reserves. They can, reinvest the capital released in new credits and profit from their interests. This simple reasoning is, in fact, much more complicated in reality. It shows the close relationship between the choice of the complementarity of the two types of information and the improvement of banks performance. This performance can be measured by several indicators. The most used are stock exchange profitability and accounting profitability. We will be interested in the latter to give an internal aspect to our study.

Concerning this type of performance, we'll concentrate on the return on equity, the return on assets, and banks credit portfolio quality. We'll use, as measuring instruments, the ratios ROE, ROA and the quality of the credit portfolio. ROE ratio was chosen by several authors such as Holderness \& Sheehan (1988) but its disadvantage remains in the risk to give a biased image of profitability since a strong ratio can be the result of a low level of equities. As for ROA ratio, it was used by Barro \& Barro (1990), Angbazo \& Narayanan (1997) and Yan (1998). The disadvantages of this measurement are the negligence of the activities off-balance sheet which becomes more extensive in banking activity, and the placement of the totality of the assets at the same level of risk.

HYP 9: the integration of "soft" information in scores improves the banks performance.

\section{Data and variables}

Finding a relationship between the choice of information and the various determinants, described above, obliges us to seek data beyond public information. Several determinants of 
the information choice, as well as the description of the decision-making process, do not exist in the databases. Moreover, the evaluation of the real costs of "soft" information is very difficult to realize. Consequently, the research for all these data lead us to distribute a questionnaire, described in the following paragraph, in addition to financial data collected from a database.

\subsection{Data}

To test the assumptions above-presented we collected the data by two means: financial data collected in the database BANKSCOPE, concerning 17 banks which belong to our sample for the year 2007, and a questionnaire distributed to the bank agency managers and loan officers. The targeted agencies are turned towards professionals and firms. They cover all the French territory and their distribution is a representative panel regarding all agencies in France. We had well specified in the questionnaire that the required data should relate to the credits supplied to SMEs during the year 2007 in order to combine them with the data collected from the database. According to the European regulation of 2003 we consider as SMEs (small or medium enterprises) any company that accounts less than 250 employments with a turnover that doesn't exceed 50 million Euros or the balance sheet total does not exceed 43 million Euros.

The final version of the questionnaire is presented in appendix 1. It was tested on under sample of 50 agency managers and loan officer responsible for SMEs. Several questions were modified in order to adapt to the requirements of the contacted professionals. The questionnaire was anonymous in order to respect the confidentiality right. We asked that the name of the bank be notified in order to complete the financial data collected in the base. The first part of the questionnaire is composed of six questions intended for collecting information on the agency (its size, the number of its employees and its geographical site). The second part relates to various information on the supplied and failing credits (size, the number), and the customer portfolio of the bank. Third rests on the decision-making process of the agency (the disclosure of the decision, the relationship and the nature of information).

The description of the sample: We distributed 2134 questionnaires for 142 answers (that is to say 6,65\%), among which we retain 105 exploitable (5\%). These answers have neither missing data nor incoherent information. The 17 French and foreign banks, composing the sample, exert on the French territory.

\subsection{Variables}


This paragraph presents all of the variables used in our study and its various measurements. At the end of the paragraph, a first table will summarize the various variables tested by the regressions and a second table will present the descriptive statistics of the qualitative variables concerning the decision-making process.

The dependant variables of the two regressions:

- The nature of information used by the bank (INFO) is a dummy variable collected by the questionnaire. It takes a binary value (INFO $=0$ if the bank uses only "hard" information for the decision-making, and INFO=1 if the bank uses the two types of information). It is the most important variable. It enables us to distinguish between banks that choose the complementarities of "soft" information and "hard" information or those substitute the first by the second.

- The bank performance is measured by the adequacy between the profitability and the risktaking. Thus, in order to measure the bank performance, we'll use three indicators: The return on assets (ROA), return on equities (ROE) and the quality of the loan portfolio (RIS_PF). The first two indicators of performance are used to show a possible change of profitability following the change of the strategy of collection, treatment and storage of information. And the third allows the measurement of the influence of this same change on the quality of the banks loans.

The two ratios of profitability, ROA and ROE, represent respectively, a fraction of the net income by the total assets of the bank and by total equities. These two variables are easy to calculate contrary to the measurement of the credit quality which was calculated from the loan loss provisions. Dividing this provision by the gross value of loans gives the ratio quality of loan portfolio, which indicates losses related to the degradation of the credits and gives a sign for futures difficulties.

\section{Independent variables:}

- The average credit: it is the ratio of the entire amount of total credits to the number of the granted credits. These data were collected from the questionnaire.

- The time of treatment of credit request allows us to study a possible effect of the available time to study a credit request on the choice of information. With the number of requests to study and the limited available time, the loan officer must be more optimal in the data treatment. 
- The length of the relationship: by this variable we tried to measure the time needed by the loan officer or the bank agency manager to collect sufficient "soft" information to make an opinion on the situation and the manager of the firm.

- The frequency of meetings: This variable comes to supplement the variable LENGTH. Indeed the length of the relationship explains the force of the relationship but it does not show the true depth and the solidity of this relationship. The frequency of the appointments allows studying his effect on the choice of information.

- The centralization of the decision: the delegation of the credit supply decision can affect the information used for the decision making. The difference between the hierarchical levels of the decision-making will be presented by a dummy variable. If the decision is made within the agency, that will be considered as a decentralization of the decision and the variable will take a value of 0 . If the decision is made outside the agency: an engagement office or others, we will consider that the bank centralizes the decisionmaking and we'll give a value equal to 1 to this variable.

- Times of the reply: it represents the number of the days necessary to answer to loan application. By this variable we tried to see whether the promised time, to answer the requests, affects the choice of information.

- Treatment of a first loan application: This dummy variable is collected by questionnaire (FIRST_REQ $=0$ if the agent uses the same type of information for all the loan applications, FIRST_REQ=1 if information changes the later requests). This variable tries to see whether the treatment of a first request differs from the treatment of another later and thus whether an adoption of "soft" information exists. This difference is explained by the effect of the experience or by the knowledge of SMEs historic, which reduces the effort of collection and treatment of information.

- Size of bank: the size of the bank is represented by the total assets. But for its use we will base the value given by the function Napierian logarithm.

- The risk of the bank: the measurement of the risk is indexed on letters by the three agencies of ratings adopted by our study. We'll try to allot values to the three notations of STANDARD \& POORS, MOODY' S and FITCH. A bank having a good notation will have a note higher than a bank having a less good notation. The scale goes from 0 to 10 . The three notations are very close and ordered that did not influence the average assigned to the banks.

- The time of collection, treatment and storage of information: the cost of the collection, the treatment and the storage of information is difficult to quantify. To measure this cost we compared it to complementary time to that usually devoted to the follow-up of a 
relationship with SMEs. Complementary time, on which we based to explain the cost of information, must be necessarily exclusive to the collection, the treatment and storage of the information used. This stays a try to explain the influence of the cost of information on the choice of the banks through the time necessaries for the loan officer.

- Default probability: this variable is calculated on the basis of notation of STANDARD \& POORS. It gives the probability of failure of the bank on the basis of one year.

Control variables:

Banks have recourse to private information which is different from that used by the other financial institutions and which is based on a personal interpretation of the loan officer concerning the situation of the SMEs. A relational method to obtain "soft" information missed in the financial documents is better adapted but more difficult to standardize. Specificities of SMEs require a particular treatment by their banks and specificities of banks influence their work methods. For this reason we tried to integrate some variables of control which permit us to see their effect on the various results.

We were interested in three criteria: nationality, membership of a group and the nature of shareholding.

The nationality of the bank can affect the choice of the information used for the decision making. The relationship of SMEs with the foreign banks is particularly fragile. These banks do not prefer to use "soft" information; they maintain businesses with the largest, oldest and most transparent companies. This choice is strategic so that these banks make the most of "hard" information (Berger \& $\mathrm{Al}$ 2008). They can be penalized by the cultural and linguistic differences during the collect of "soft" information (Berger \& Udell 2002). This idea was confirmed by Berger \& Al (2008) by supporting that firms which have relationships with the foreign banks have the will to establish several relationships.

The membership of a group can affect banks behaviour. A small bank which belongs to a "holding" can behave like a large bank (Keeton 1995, Berger \& Al 2001 and Carter \& Mc Nulty 2005). A small bank which uses "soft" information can have to use "hard" information in order to align itself to the information system of the group.

The last distinction is made between commercial and mutual banks. The activity of these last is based on a particular ideology. Thus their work method and their standard of the established relationship are different from the commercial banks. The particularity of the customersshareholders in the mutual banks requires more developed information.

The measurement of the variables: 
- The nature of the shareholding: the structure of shareholding of a bank will be presented by variable BK_MUT. This variable takes binary value. It is equal to 1 if the bank is mutual, 0 if not.

- Membership of group: a dummy variable will indicate weather the bank belongs to a group or not. If the bank belongs to a group, this variable (BK_GRP) will take value 1, and if it is independent the variable will be equal to 0 .

- The nationality of the bank: a dummy variable allowing to distinguish between the French and foreign banks which exert in France. This variable has a binary value (BK_NAT $=1$ if the bank is national, BK_NAT=0 if it is foreign).

\section{$\underline{\text { Table } 1}$}

This table presents the various variables taken into account in our regressions. The second column encodes the results of the realized tests. The mention "accounts annual" indicates that the variables are calculated from the collected data of income statement of the bank, and the mention "credit rating agency" makes reference to the agencies of STANDARD ratings \& POORS, FITCH and MOODY' S.

\begin{tabular}{lll}
\hline The variable & The code & The source \\
\hline Used Information & INFO & Questionnaire \\
Return on assets & ROA & Annual accounts \\
Return on equity & ROE & Annual accounts \\
The quality of the portfolio credit & QLTE_PF & Annual accounts \\
The average size of credits & AVR_CR & Questionnaire \\
Treatment time of an loan application & TIME_TR & Questionnaire \\
Length of the relationship with a borrower & LENGTH & Questionnaire \\
The frequency of the FRQ_MEETING & FRQ_MEETINC Questionnaire \\
The hierarchical level of the decision-making & HIER & Questionnaire \\
The deadline for reply & REPLY & Questionnaire \\
Treatment of a first request & FIRST_REQ & Questionnaire \\
The size (Log of the assets) & ASSETS & Questionnaire \\
The index of the bank risk & RISK & Credit rating agency \\
Costs in term of time of the collection, of \\
treatment and of the storage of used information
\end{tabular}




\section{$\underline{\text { Table } 2}$}

Table 2 presents descriptive statistics of our qualitative variables. The entire answers rise from the questionnaire distributed to the agency managers and loan officers in charge of the credits of SMEs.

The first panel shows the various rates of use of each type of information for the decisionmaking, for short-term credits or long-term. The second panel gives us the participation of the various variables in the delegation of the credit decisions. The third one has the rates of the various variables influencing the decision-making.

\section{Information source}

\begin{tabular}{|l|l|l|}
\hline & Short Term Credit & Long Term credit \\
\hline Financial analysis & $103(98,10 \%)$ & $105(100 \%)$ \\
\hline Cash analysis & $94(89,52 \%)$ & $84(80 \%)$ \\
\hline Current accounts & $62(59,05 \%)$ & $77(73,33 \%)$ \\
\hline An appointment & $96(91,43 \%)$ & $88(83,81 \%)$ \\
\hline A judgment of loan officer & $53(50,48 \%)$ & $66(62,86 \%)$ \\
\hline Competences of the manager (CV) & $68(64,76 \%)$ & $79(75,24 \%)$ \\
\hline The history of the credits & $48(45,71 \%)$ & $65(61,9 \%)$ \\
\hline A report of the French Central Bank & $33(31,43 \%)$ & $57(54,29 \%)$ \\
\hline $\begin{array}{l}\text { A report of another bank which exerts with } \\
\text { the same firm but before your Bank }\end{array}$ & $6(5,71 \%)$ & $11(10,48 \%)$ \\
\hline
\end{tabular}

\section{Variables of the delegation of the decision}

\begin{tabular}{|l|l|}
\hline Global economic conjuncture & $37(35,24 \%)$ \\
\hline Risk of the business line of SMEs & $56(53,33 \%)$ \\
\hline Quality of financial data & $86(81,9 \%)$ \\
\hline Size of the SMEs & $31(29,52 \%)$ \\
\hline Finality of the credit & $45(42,86 \%)$ \\
\hline Risk of the SMEs & $80(76,19 \%)$ \\
\hline Size of credit & $74(70,48 \%)$ \\
\hline
\end{tabular}




\begin{tabular}{|l|l|}
\hline The strength of the relationship with SMEs & $84(80 \%)$ \\
\hline A judgment of the future situation of SMEs & $78(74,29 \%)$ \\
\hline Future projects of the borrower & $60(54,14 \%)$ \\
\hline Competences of the manager & $91(86,67 \%)$ \\
\hline Your "feeling" & $47(44,76 \%)$ \\
\hline The estimate of the guarantees value & $67(63,81 \%)$ \\
\hline An extra-professional relationship & $17(16,19 \%)$ \\
\hline
\end{tabular}

\section{Regressions}

\subsection{Methodology}

Our work consists on three parts. The first part relates to a logistic regression of the variable information (INFO) to determine the significativity of the various determinants taken into account in the regression. In the second part, we'll study the effect of the choice of information on the bank performance and the third part presents a statistical description of the integration of the various qualitative variables in the decision-making process.

Since the dependant variable of our first regression is a dummy variable, the use of a logistic model of regression seems more adequate for our study. The choice between the model Probit and Logit is not very important. In our sample, we have observed that the phenomenon at which we attributed the binary value 1 is more frequent which is why we used the Logit model.

Our first regression is in the form:

$$
\begin{aligned}
& \operatorname{Ln}\left[\frac{\mathrm{P}(1 / \mathrm{INFO})}{1-\mathrm{P}(1 / \mathrm{INFO})}\right]=\quad \begin{array}{l}
\alpha_{0}+\alpha_{1} \text { FIRST_REQ }+\alpha_{2} \text { LENGTH }+\alpha_{3} \text { FRQ_MEETING }+ \\
\alpha_{4} \text { TIME_TR }+\alpha_{5} \text { REPLY }+\alpha_{6} \text { AVR_CR }+\alpha_{7} \text { ASSETS }+\alpha_{8}
\end{array} \\
& \text { HIER }+\alpha_{9} \text { COST }+\alpha_{10} \text { RISK }+\alpha_{11} \mathrm{DP}+\varepsilon
\end{aligned}
$$

In the second part, we'll try to explain profitability and the loss provisions of bank by the adopted choice of information. To do so, we used regressions of ordinary least squares (OLS). We carried out this second regression in two stages. In the first stage, we integrated only one independent variable: INFO. In the second stage, we integrated other variables of control to eliminate biases related to specificities from the bank. The adopted variables relate to three characteristics of the bank: its membership of group, its nationality and the nature of its shareholding. (BK_GRP, BK_NAT and BK_MUT). 


\begin{tabular}{|l|l|}
\hline \multicolumn{1}{|c|}{ First stage } & \multicolumn{1}{c|}{ Second stage } \\
\hline $\mathrm{ROA}=\beta_{0}+\beta_{1} \mathrm{INFO}+\varepsilon$ & $\mathrm{ROA}=\beta_{0}+\beta_{1} \mathrm{INFO}+\beta_{2} \mathrm{BK} \_\mathrm{GRP}+\beta_{3} \mathrm{BK} \_\mathrm{NAT}+\beta_{4} \mathrm{BK} \_\mathrm{MUT}+\varepsilon$ \\
\hline $\mathrm{ROE}=\gamma_{0}+\gamma_{1} \mathrm{INFO}+\varepsilon$ & $\mathrm{ROE}=\gamma_{0}+\gamma_{1} \mathrm{INFO}+\gamma_{2} \mathrm{BK} \_\mathrm{GRP}+\gamma_{3} \mathrm{BK} \_\mathrm{NAT}+\gamma_{4} \mathrm{BK} \_\mathrm{MUT}+\varepsilon$ \\
\hline $\mathrm{RIS} \_\mathrm{PF}=\lambda_{0}+\lambda_{1} \mathrm{INFO}+\varepsilon$ & $\mathrm{RIS} \_\mathrm{PF}=\lambda_{0}+\lambda_{1} \mathrm{INFO}+\lambda_{2} \mathrm{BK} \_\mathrm{GRP}+\lambda_{3} \mathrm{BK} \_\mathrm{NAT}+\lambda_{4} \mathrm{BK} \_\mathrm{MUT}+\varepsilon$ \\
\hline
\end{tabular}

The third part of our study presents a statistical description of the various variables that could influence the decision-making process of the bank.

\subsection{Results and discussions}

Results of our first regression are presented in table 1.The Pseudo- $\mathrm{R}^{2}$ of McFadden had a value equalizes to 0,239 . We found statistical significativity for five among the eight assumptions studied by this first regression.

The not validated assumption is the sixth. Indeed, according to the results of the regressions, we can conclude that the hierarchical level of the loan decision-making does not influence the choice of information.

The assumptions about which one cannot come to a conclusion are the third and the eighth. Concerning, the third assumption which is supporting the idea that the constraint of time supports the substitution of "hard" information to "soft" information, it is tested by two variables: REPLY which represents the times required to answer the loan application and the variable TIME_TR which indicates time estimated to treat a request. We cannot come to a conclusion about the validity of this assumption because the variable REPLY did not have a statistical significativity, in spite of the positive sign allotted to this variable confirming that a longer time gives the possibility to use the two types of information, thus confirming our proposal. The other variable TIME_TR, which is statistically significant, had a minus coefficient, in accordance with our expectations. This result can be explained by the fact that a longer processing time allows loan officer analyzing well "hard" information. It takes the time necessary to analyze all the financial information at its disposal, in order to take the good decision. A short time of treatment obliges the loan officer to reduce the "hard" information retrieval and to support the use of "soft" information which is already collected. He will combine the two types of information to decide.

It is difficult to decide concerning the validity of the last assumption which makes it possible to measure the effect of risk on the choice of adopted information. The measurement of risk was studied by integration in the model of two variables: the risk of bank (RISK) and probability of default (DP). This last variable is not statistically significant, whereas it was 
negatively correlated with the complementarity of the two types of information. This first result, in spite of its non-significativity, enables us to say that the fall of the probability of default pushes the banks to adopt "hard" information which seems to be more exact and more rigid. The variable RISK is significant and is negatively correlated with the adoption of the only "hard" information. This fact confirms the assumption that the use of the complementarity between the two types of information is negatively related to the risk of the bank. The integration of "soft" information contributes to the improvement of the quality of information and thus it minimizes the catch of the false decisions.

All remaining assumptions are validated. Indeed, we note that the sign of the coefficient of variable FIRST_REQ is positive, which explains why the officer charged with SMEs do not use the same type of information for all credit applications. They tend to use "soft" information in addition to "hard" information for the later requests. This confirms our first assumption according to which the information used at the time of the first request, and which can be only "hard", is different from that used later on.

The second assumption is tested by two variables: the length of the relationship (LENGTH) and the frequency of appointment (FRQ_MEETING), necessary for the loan officer for SMEs, in the collection of "soft" information and the acquisition of an opinion on the situation of the firm. These two variables must measure the force of the relationship. They had $\mathrm{T}$ of Student significant but opposite signs of the coefficients. The sign of the frequency of the FRQ_MEETING is positive, which can be explained by the fact that the number of the appointment supports the collection of "soft" information and the construction of an image which reflects the real situation of SMEs. Contrariwise, the LENGTH of the relationship (LENGTH) admits a minus coefficient, which is explained by the fact that one very long period for the collection of "soft" information can harm its reliability. The longer the period of collection is, the less it reflects the real situation of the firm. Our assumption is thus validated and confirms that the contact supports the collection of "soft" information.

The regression carried out shows us that, in accordance with the statements of the fourth assumption, the average amount of credits is negatively correlated with the complementarity of the two types of information. Indeed, variable AVR_CR had a coefficient close to -0,20. The increase in the intermediate size of the credits leads to the use of the only "hard" information and thus eliminates any assessment or personal judgment. We can explain this result by the fact that, in the case of an important credit, banks try to be more protected against a possible failure. Thus they try to minimize the margins of interpretation and judgment and to choose financial information which is reliable and easy to control. Banks support the facility of control of large borrowers for better allocating their resources. 
Still in the negative correlations, the bank size, represented by the variable ASSETS, is negatively related to the combination of the two types of information. This report confirms the fifth advanced assumption and supporting the idea that large banks approve the use of the only "hard" information, and thus confirms all the theories which predicted that the big size of the bank is an important variable for the generalization of the quantitative models of evaluation.

Moreover, seventh assumption, which predicts that the cost of the collection, of treatment and of storage of information can affect the choice of the type of information used, is validated. As a matter of fact, the variable COST, measured by the time necessary for the information collection, treatment and storage, was negatively correlated with the use of "hard" information alone. In other words, the fall of the information cost, used for the request handling, can explain the substitution of "soft" information by "hard" information. This variable can be shown similar to the variable LENGTH, but in reality it does not represent the same measurement of time. One measure the time necessary to judge the situation of SMEs and the other evaluate the time necessary to collect, treat and store the useful information in the decision-making.

In order to test the robustness of our model, we carried out the test of collinearity which measures the factors of inflation of variance. This test showed the absence of collinearity between our independent variables. It is important to note that all of the securities of the test do not exceed 3 whereas the maximum value to accept the assumption of absence of collinearity is valued at 10 .

Our second part was carried out into two steps. The results of the first three regressions are presented in table 2 in the appendix. They show a statistical significativity, with $1 \%$ of error, of the influence of the nature of information on the return on equity and the quality of the wallet credit. Indeed, with $\mathrm{T}$ of Student having respective values of 3,206 and of - 2,668, we can conclude the significativity of the variable INFO. The positive coefficient of the variable INFO in the regression performed on the ROE shows that the choice of the complementarity of information influences positively this profitability. Moreover, the variable INFOR was affected negatively with variable QLTE_PF. A low value of this ratio can be interpreted as a good quality of the wallet credit. Thus the negative sign, between the complementarity of the two information and this variable shows a good influence of the complementarity on the quality of the credits. However, the significativity of this variable in explaining the economic profitability of the bank is verified to only $10 \%$ of error. This suggests that the level equities could skew the interpretation of the first result. 
We carried out a second regression by taking in account three variables which we think are capable to influence the bank performance: its nationality, its membership of group and the nature of its shareholding. The results of this second regression (table 3 of the appendix) confirm those of the first. Indeed, the significativity and the sign of the variable INFO remain unchanged for the three variables which measure the performance. What minimizes biases related to the membership of the bank to a group and the nature of its shareholding.

At the time of the two steps, we carried out tests on the robustness of the model and we confirmed the null assumption of absence of heteroscedasticity in the six regressions realized and the assumption of absence of collinearity between the explanatory variables for the regressions of the second phase.

The third part of our empirical study will relate to a statistical description of the decisionmaking process of the agents of credit.

The first under part will show the various information sources used for the decision-making. We note that almost all the loan officers use the financial data for the study of the short-term and long-term loan applications. But the "soft" information sources are used, for the credits with Long Term, that for those with Short Term except for the FRQ_MEETING (91\% for the ST compared with $83 \%$ for the LT). The most outstanding fact of this part remains the percentage of loan officers which uses their personal judgments as information source (50\% for the ST and $66 \%$ for the LT). The other point which needs to be underlined is the weak coordination between banks. Only $5,71 \%$ for the ST and $10,5 \%$ for the LT, of bankers who respond to our questions use report of other banks working with the same customer and having an older relationship. However, the report of the bank of France is used by 55\% of these respondent for a LT credit but only $31 \%$ for the ST.

A test of differences of means was carried out in order to look for a significant difference between the information sources used during the treatment of the long-term credits and the short-term credits. After having tested the difference of the variances and obtaining a result confirming the absence of a statistically significant difference, we realized the test of the difference of the means under the assumption of equality of the variances. We could not reject the null assumption thus confirming an equality of the means. We deduce from it that there exists a similarity of treatment of the short-term and long-term credits (Table 4).

The second part of this descriptive analysis will allow us to present the various variables of delegation of decision making. The two more important variables, according to the respondents, are the quality of the financial data for $82 \%$ of the cases and the risk of the SMEs for $76 \%$. The size of the credit also involved in the choice of the decentralization of the 
decision-making, but in a less important scale than the two previous. Nearly $70 \%$ of the respondents confirm that the level of the decision-making depends on the amount of credit. But the most important fact is that the characteristics of the borrowers, such as the size of SMEs and the finality of the credits intervene in the decision of delegation, with respective percentages of use of $29,5 \%$ and $42 \%$. With regard to the total economic conjuncture, it intervenes only in $35 \%$ of the cases, which shows the bad adaptation of the decision-making processes to the environmental changes. This organizational rigidity enables us to wonder about the procedural flexibility of the bank. If a bank doesn't adapt its management to the requirements of the market, it will be found in difficulty to optimize its activity and to exploit its assets.

The third under part will show the various variables which influence the decision of the granting of credit and the importance of "soft" information in this decision.

As opposed to our expectations, the variable that most influences the decision, remains "competences of manager", with a very high utilization ratio. Indeed $86 \%$ of loan officers specify that they were affected by competences of the manager at the time of the decisionmaking.

The strength of the relationship is less important according to the respondents but its utilization ratio remains nevertheless high, $80 \%$ of the latter confirmed to have changed the decision into being based on the strength of their relationship with SMEs. Personal interpretation, of the loan officer remains important in the sources of the information used for the credit supplying decision-making, with a percentage of use close to $45 \%$. The most outstanding point, of this table, remains the weight of the professional extra relationships in the judgment of the banker. Indeed, in more than one case out of six, loan officers for SMEs and the agency managers are based on professional extra relationships to influence or make influence the decision of credit. However, the judgment of the future situation of SMEs, the assessment of the guarantees and the future projects of the borrower, which are having respective frequencies of uses of $75 \%, 64 \%$ and $54 \%$, are shown under exploited by taking account of their importance in the justification of the taken risk level.

The conclusion to be drawn from this paragraph is that the use of "soft" information in the credit granting decision is very widespread. It remains to find the means of optimizing its exploitation. This information is difficult to quantify, but regarding its importance, it was necessary to find a solution to formally control it and integrate it in the calculation of the scores and the notations assigned to SMEs. 


\section{Conclusion}

In an unfavourable international economic conjuncture, banks must face an increasing difficulty of credit supply. They must optimize the allowance of their assets, during one time characterized by an outstanding absence of financial credibility. In spite of the fact that SMEs represent the most important components of French economic fabric, they suffer from a great vulnerability related to their opacity. The financial information alone can't allow this category of firm to take profit from the credits.

"Soft" information which is collected throughout the relationship, connecting the banks and SMEs, seems necessary to reduce the problem of informational asymmetry. The committee of Basle incites banks to use more specific internal scores for the evaluation of their customers, but these scores compromise the advantages related to the "soft" information treatment.

Our work proved the statistical significativity of eight variables, among eleven suggested, to explain the choice of the complementarity or substitution between the used information. This significativity made it possible to validate five assumptions, to invalidate one and not to decide concerning two others. These first studies showed that the choice of information affects the quality of the informational inputs of the credit decision.

We tried in the second part of this work to find a relationship between this choice of information and the banking performance, but we could not validate the assumption supporting the idea that the complementarity of information used improves the banking performance. Contrary and concerning risks we could observe a negative relationship between the complementarity of the two types of information and the quality of the bank credit portfolio and this can be explained by the fact that "soft" information is merely subjective.

On the practical level, in spite of the weak relationship between the performance of the bank and the exploitation of "soft" information, the loan officer responsible for SMEs essentially uses this type of information to slice in the credit decision.

Regarding responses gave by bankers, we can conclude about the importance of the use of this information in the decision-making. This information is probably important for making the best decision and the minimization of the taken bank risk, but it remains to standardize it and integrate it in the notations and the scores attributed to SMEs. This standardization is difficult to realize and opens the horizon with a new control system of the treatment of the loan applications. The difference between the imposed rules and the practice will grow blurred to leave the place with a blind application of the mathematical models and the calculation of the financial scores what will push banks to make arbitration between risks taking and credit rationing. 


\section{Bibliography}

- Aghion. P \& Tirole. J, « Formal and Real Authority in Organizations », Journal of Political Economy, vol. 105, n 1 , February 1997, 1-29.

- Akhavein J, Frame W.Scott \& White L. J, «The Diffusion of Financial Innovations: An Examination of the Adoption of Small Business Credit Scoring by Large Banking Organizations », Journal of Business, University of Chicago Press, vol. 78, n², March 2005, 577-596.

- Angbazo L \& Narayanan R, «Top management compensation and the structure of the board of directors in commercial banks », European Finance Review, Vol. 1, 1997, 239259.

- Barro J \& Barro R. J, « Pay, performance and turnover of banks CEOs », Journal of Labor Economics, vol.8, 1990, 448-481.

- Berger A. N, «The economic effects of technological progress: evidence from the banking industry» Finance and Economics Discussion Series 2002-50, Board of Governors of the Federal Reserve System (U.S.), 2002.

- Berger A. N \& Deyoung R, «The effects of geographic expansion on bank efficiency», working paper, Federal Reserve Bank of Chicago, 2000.

- Berger A. N \& Frame W. Scott, « small business credit scoring and credit availability », Federal Reserve Bank of Atlanta Working Paper Series 2005-10 May 2005.

- $\quad$ Berger A. N, Frame W. Scott \& Miller N. H., « credit scoring and the availability, price, and risk of small business credit », Journal of Money, Credit, and Banking - vol. 37, Number 2, March 2005, 191-222.

- $\quad$ Berger A. N, Klapper L F, Martinez Peria M. S \& Zaidi R, «Bank ownership type and banking relationships », Journal of Financial Intermediation vol.17, 2008, 37-62

- Berger A. N, Klapper L. F \& Udell G. F, «The ability of banks to lend to informationally opaque small business», journal of Banking and Finance, vol.21, 2001, 2127-2167.

- $\quad$ Berger A. N, Miller N. H, Petersen M. A, Rajan R. G, \& Stein J. C, «Does function follow organizational form? Evidence from the lending practices of large and small banks », Journal of Financial Economics, vol. 76(2), 2005, 237-269.

- $\quad$ Berger A. N, Saunders A, Scalise J. M, \& Udell G. F, « The effects of bank mergers and acquisitions on small business lending ». Journal of Financial Economics, vol. 50, 1998, $187-229$. 
- Berger A. N \& Udell G F, «Universal Banking and the Future of Small Business Lending. » In Universal Banking: Financial System Design Reconsidered, Chicago, IL: Irwin, 1996, 558-627.

- Berger A. \& Udell. G, «The economics of small business finance: The roles of private equity and debt markets in the financial growth cycle », Journal of Banking and Finance, vol. 22, 1998, 613-73.

- Berger A. N \& Udell G. F, «Small Business Credit Availability and Relationship Lending: The Importance of Bank Organisational Structure », Forthcoming, Economic Journal, 2002.

- Berger A. N, \& Udell G. F, «A more complete conceptual framework for SME finance » Journal of Banking and Finance, vol. 30, N¹1, 2006, 2945-2966.

- Boot A. W., «Relationship Banking: What Do We Know?», Journal of Financial Intermediation, vol. 9, 2000, 7-25.

- Carter D. A \& Mc Nulty J. E, «Deregulation, technological change, and the businesslending performance of large and small banks» Journal of Banking \& Finance, vol. 29, 2005, 1113-1130.

- Cole R. A, « The importance of relationships to the availability of credit », Journal of Banking and Finance, vol. 22 (6-8), 1998, 959-977.

- Cole R, Goldberg L.G. \& White L.J, «Cookie-cutter versus character: the micro structure of small business lending by large and small banks ». Journal of Financial and Quantitative Analysis, vol. 39, 2004, 227-251.

- $\quad$ DeYoung R, Glennon D \& Nigro P, «Borrower-lender distance, credit scoring, and loan performance: Evidence from informational-opaque small business borrowers » Journal of Financial Intermediation, vol. 17(1), January 2008, 113-143.

- DeYoung R, Hunter W. C, \& Udell G. F, «The past, present, and probable future for community banks », Journal of Financial Services Research, vol. 25 (2-3), 2004, 85-133.

- Elsas R, «Empirical determinants of relationship lending », Journal of Financial Intermediation vol. 14, 2005, 32-57.

- Elyasiani E \& Goldberg L. G, «Relationship lending: A survey of the literature » Journal of Economics and Business vol. 56 (4), 2004, 315-330.

- Feess E \& Hege U, « The Basel II Accord: Internal Ratings and Bank Differentiation », Center for Financial Studies No. 2004/25, 2004.

- Foglia A, Laviola S \& Marullo Reedtz P, «Multiple banking relationships and the fragility of corporate borrowers », Journal of Banking \& Finance, vol. 22, 1998, 14411456. 
- Frame W. Scott, Padhi. M \& Woosley L, «The Effect of Credit Scoring on Small Business Lending in Low- and Moderate-Income Areas », Federal Reserve Bank of Atlanta Working Paper No. 2001-6, 2001.

- $\quad$ Frame W. Scott, Srinivasan A, \& Woosley L, « The Effect of Credit Scoring on SmallBusiness Lending », Journal of Money, Credit and Banking, Vol. 33, No. 3, 2001, 813825.

- Godbillon-Camus B \& Godlewski C. J, «Credit Risk Management in Banks: Hard Information, Soft Information and Manipulation », Working Paper LaRGE 2005-02.

- Godlewski C, «Rôle de la nature de l'information dans l'intermédiation Bancaire», Finance 0409029, EconWPA, 2004.

- Holderness C. G \& Sheehan D. P, « The role of majority shareholders in publicly held corporations: An exploratory analysis », Journal of Financial Economics, Elsevier, vol. 20(1-2), 1988.

- Keeton W, «Equilibrium Credit Rationing », New York, Garland Press, 1979.

- Keeton. W, «Multi-office bank lending to small businesses: Some new evidence », Economic Review, Federal Reserve Bank of Kansas City, vol. 80, 1995, 45-57.

- $\quad$ Liberti J. M, «Initiative, Incentives and Soft Information. How Does Delegation Impact The Role of Bank Relationship Managers? » Finance 0404023, EconWPA, 2004.

- $\quad$ Lobez F, « le rationnement du crédit : une synthèse », finance, vol. 9, $\mathrm{N}^{\circ} 2,1988$.

- $\quad$ Lummer, S. L., \& McConnell, J. J. «Further evidence on the bank lending process and the capital market response to bank loan agreements », Journal of Financial Economics, 25(1), 1989, 99-122.

- $\quad$ Petersen, M.A, «Information: Hard and soft », Mimeo, Kellogg School of Management, Northwerstern University, 2004.

- Petersen, M. A \& Rajan R. G, «The Effect of Credit Market Competition on Lending Relationships », The Quarterly Journal of Economics, MIT Press, vol. 110(2), May 1995, 407-443.

- Petersen M. A., \& Rajan R. G, « Does distance still matter? The information revolution in small business lending », Journal of Finance, vol. 57, 2002, 2533-2570.

- Stein J. C, «Information production and capital allocation: decentralized versus hierarchical firms ». Journal of Finance, vol. 57, 2002, 1891-1921.

- Udell G. F, «What's in a relationship? The case of commercial lending », Business Horizons, vol. 51, 2008, 93-103.

- Uzzi B \& Gillespie J. J, «What small firms get capital and what cost: notes on the role of social capital and banking networks », Proceedings, Federal Reserve Bank of Chicago, 1999. 
- Vos E, Yeh A. J-Y, Carter S \& Tagg S, « The happy story of small business financing », Journal of Banking \& Finance, vol. 31, 2007, 2648-2672.

- Yan Y, « The FDICIA and bank CEO's pay-performance relationship: An empirical investigation », Working Papers, Federal Reserve Bank of Cleveland, № 9805, January 1998.

\section{Appendices}

\section{Appendix 1: The questionnaire}

\section{General information on the agency}

We will begin our questionnaire with the general collection of information concerning the agency which you supervise. The required data must relate to the year 2008. Some questions only are concerned with this precision.

1. With which banking network belongs the agency which you manage?

2. Can you give us the full number of the people who work within your agency and the number of loan officers responsible for SMEs?

\begin{tabular}{|l|l|}
\hline The full number & \\
\hline The loan officers responsible for & \\
SMEs & \\
\hline
\end{tabular}

3. How much you think the amount of personnel expenses for this agency?

4. How much is the total operating expenses of the agency?

5. Can you specify the size of the city in which you exert your work?

\begin{tabular}{|l|l|l|l|}
\hline+ of 200000 & Between & - of 50000 & countryside \\
residents & $\begin{array}{l}200000 \quad \text { and } \\
50000 \text { residents }\end{array}$ & residents & \\
\hline & & & \\
\hline
\end{tabular}

6. Can you estimate the Net Banking Income of your agency? 


\section{Information on the credits}

In this second part of the questionnaire, we will pass to information concerning the credits and the client portfolio of the branch. I remind to you that the data sought target loans to SMEs during the year 2008.

7. How much you think the total amount of the credits supplied by your agency?

8. Can you give us the number of credits granted by the agency?

9. Can you communicate the rejection rate of loan applications treated by your agency? (the number of negative responses to the granting of credit after a request study)

10. What was the total value of the SMEs loans default? (the default credits are those which present a default payment of 90 days or more)

11. What is the full number of credits considered failures during 2008 ?

12. Can you specify us if there exists a system of internal rate of transfer?

\section{YES NOT}

13. If YES, can you give us the cost of refinancing paid by the agency to be able to supply the credits SMEs?

14. Can you tell us how is established the refinancing rate?

15. Can you estimate the number of hours necessary for loan officer responsible for SMEs to study a loan application according to the amount and of the duration of credit?

\begin{tabular}{|l|l|l|}
\hline & Short-term credit & Long-term credit \\
\hline Less than $10.000 €$ & & \\
\hline Between $10.000 €$ and & & \\
$100.000 €$ & & \\
\hline More than $100.000 €$ & & \\
\hline
\end{tabular}

16. Can you give us the share of each economic sector in the customer portfolio of your agency?

Agriculture

Industry.

Service

17. From how long established relationship allows you to build a sufficient personal idea to judge the SMEs manager without recourse to the updated financial data? 
18. After how many appointments you can build a sufficient personal idea to judge the SMEs manager without recourse to the updated financial data?

19. Can you estimate the customer portfolio risk of your agency (Tick the box which appears representative to you)?

\begin{tabular}{|l|l|l|l|l|l|}
\hline Very risky & Risky & $\begin{array}{l}\text { Moderately } \\
\text { risky }\end{array}$ & low risky & $\begin{array}{l}\text { Slightly } \\
\text { risky }\end{array}$ & No risky \\
\hline & & & & & \\
\hline
\end{tabular}

\section{General information on the credit decision-making}

Now, we will approach the various elements which influence the credit decision making. For the multiple choice questions, please tick the answer which appears good to you.

20. According to your processes, can you give us the origins of the used information during the treatment of a loan application of short term and long term credits (to tick the boxes which seems to you adequate)

\begin{tabular}{|l|l|l|}
\hline & Short-term credit & Long-term credit \\
\hline Financial analysis & & \\
\hline Cash analysis & & \\
\hline Current accounts & & \\
\hline An appointment & & \\
\hline A judgment of loan officer & & \\
\hline Competences of the manager (CV) & & \\
\hline The history of the credits & & \\
\hline A report of the French Central Bank & & \\
\hline $\begin{array}{l}\text { Of another bank which exerts with } \\
\text { the same firm but before your bank }\end{array}$ & & \\
\hline
\end{tabular}

21. Can you tell us if you treat the information in the same way for a first loan application and subsequent requests?

YES NOT

22. Can you assess the additional time to time normally devoted to the follow-up of a relationship with SMEs and necessary to the collect, the treatment and the storage of used information to respond to a credit request? 
23. Can you give us the number of days taken to respond to a credit application?

24. Is the decision of credit taken within the agency or commitment management?

The agency (Credit management)

Commitment management (Risk management)

25. Can you specify what variables may depend on the delegation on the credit decision? (you can tick several alternatives)

\begin{tabular}{|l|l|}
\hline The global economic conjuncture & \\
\hline Risk of the business line of SMEs & \\
\hline Quality of the financial data & \\
\hline Size of the SMEs & \\
\hline The finality of the credit & \\
\hline Risk of the SMEs & \\
\hline Size of credit & \\
\hline
\end{tabular}

26. If the amount of credit affects the delegation of the credit decision, from which amount this decision is delegated to an external person at the agency?

27. According to you, can the length of service of loan officer influence the choice of used information?

YES NOT

28. To evaluate SMEs in a loan application, you use internal scores (calculated within the bank) or external scores (transmitted by the French Central Bank or others...)?

Internal score

External score

29. Take you into consideration non financial factors, in addition to the scores to decide of the request of the credit?

\section{YES NOT}

30. If the score of SMEs is lower but not far from the threshold of acceptance. Can you influence the response to the loan application?

YES NOT

31. On which elements you can rely to influence a decision of credit? (you can choose several alternatives)

The strength of the relationship with SMEs 


\begin{tabular}{|l|l|}
\hline A judgment of the future situation of SMEs & \\
\hline Future projects of the borrower & \\
\hline Competences of the manager & \\
\hline Your "feeling" & \\
\hline The estimate of the guarantees value & \\
\hline An extra professional relationship & \\
\hline
\end{tabular}

\section{TABLE 1}

Logit estimate using the 105 observations 1-105

Dependant variable: INFO

\begin{tabular}{llll}
\hline Variable & Coefficient & Std error & Statistics $T$ \\
\hline Const & 33,154 & 12,1919 & 2,7193 \\
FIRST_REQ & 0,994177 & 0,680743 & $\mathbf{2 , 4 6 0 4}$ \\
LENGTH & $-0,46225$ & 0,243964 & $\mathbf{- 2 , 0 9 4 8}$ \\
FRQ_MEETING & 0,392153 & 0,163624 & $\mathbf{2 , 3 9 6 7}$ \\
TIME_TR & $-0,535651$ & 0,27209 & $\mathbf{- 1 , 9 6 8 7}$ \\
REPLY & 0,200834 & 0,108864 & 1,8448 \\
AVR_CR & $-0,195587$ & 0,171781 & $\mathbf{- 2 , 1 3 8 6}$ \\
ASSETS & $-0,765$ & 0,253779 & $\mathbf{- 3 , 0 1 4 4}$ \\
HIER & 0,0222 & 0,637877 & 0,0348 \\
COST & $-0,540227$ & 0,217048 & $\mathbf{- 2 , 4 8 9 0}$ \\
RISK & $-2,67108$ & 1,37686 & $\mathbf{- 1 , 9 8 0 0}$ \\
DP & $-0,174433$ & 1,9415 & 0,0898 \\
\hline
\end{tabular}

Mean of INFO $=0,724$

Number of cases "correctly predicted" $=83(79,0 \%)$

$\mathrm{F}$ (beta' $\mathrm{X}$ ) at the mean of the independent variables $=0,149$

McFadden's Pseudo-R-squared = 0,239334

Log-likelihood $=-44,0691$

Likelihood ratio test: Chi-square $(11)=34,6189$ (p. value 0,001181)

Akaike information Criterion (AIC) $=116,138$

Schwarz Bayesien criterion $(\mathrm{BIC})=149,986$

Hannan-Quinn Criterion $($ HQC $)=129,043$

\begin{tabular}{|l|l|l|l|}
\cline { 2 - 4 } \multicolumn{1}{c|}{} & \multicolumn{3}{l|}{ Predicted } \\
\hline \multirow{4}{*}{ Current } & & 0 & 1 \\
\cline { 2 - 4 } & 0 & 15 & 14 \\
\cline { 2 - 4 } & 1 & 8 & 68 \\
\hline
\end{tabular}


Test of collinearity:

Variance Inflation Factors

$\operatorname{VIF}(J)=1 /\left(1-R(J)^{\wedge} 2\right)$, where $R(J)$ is the multiple correlation coefficient between the independent variable $\mathrm{J}$ and the other variables

Possible minimal value $=1.0$

Value $>10.0$ can indicate a multi collinearity problem

The highest value is noted for variable ASSETS and equalizes to 2,286.

$\underline{\text { TABLE } 2}$

OLS estimates using the 105 observations 1-105

\begin{tabular}{|l|l|l|l|}
\hline & ROA & ROE & QLTE_PF \\
\hline Const & $0,287175 * *$ & $6,72053 * * *$ & $2,77065 * * *$ \\
& $(2,5045)$ & $(6,2894)$ & $(13,5313)$ \\
\hline INFO & $0,239622 *$ & $4,02691 * * *$ & $-0,642228 * * *$ \\
& $(1,7779)$ & $(3,2062)$ & $(-2,6684)$ \\
\hline R squared & 0,0297747 & 0,0907459 & 0,0646617 \\
\hline Adjusted R-squared & 0,020355 & 0,0819182 & 0,0555807 \\
\hline Test of White & $\mathrm{TR}^{2}=0,651999<$ & $\mathrm{TR}^{2}=2,55331<$ & $\mathrm{TR}^{2}=0,000385651<$ \\
& $\chi^{2}(1)=3,84$ & $\chi^{2}(1)=3,84$ \\
\hline
\end{tabular}

* Significant to $10 \%$, ** significant to $5 \%$, *** significant to $1 \%$, (T of Student).

\section{TABLE 3}

OLS estimates using the 105 observations 1-105

\begin{tabular}{|c|c|c|c|}
\hline & ROA & ROE & QLTE_PF \\
\hline Const & $\begin{array}{l}0,266331 \\
(1,1949)\end{array}$ & $\begin{array}{l}13,86625 * * * \\
(7,3164)\end{array}$ & $\begin{array}{l}2,77997 * * * \\
(7,2434)\end{array}$ \\
\hline INFO & $\begin{array}{l}0,248814 \\
(1,17550)\end{array}$ & $\begin{array}{l}4,29533 * * * \\
(3,6185)\end{array}$ & $\begin{array}{l}-0,72934 * * * \\
(-2,9877)\end{array}$ \\
\hline BK_GRP & $\begin{array}{l}0,234673 \\
(1,13666)\end{array}$ & $\begin{array}{l}-0,224956 \\
(-0,1565)\end{array}$ & $\begin{array}{l}0,919673 * * * \\
(3,1103)\end{array}$ \\
\hline BK_NAT & $\begin{array}{l}-0,134963 \\
(-0,6017)\end{array}$ & $\begin{array}{l}-6,87641 * * * \\
(-3,6617)\end{array}$ & $\begin{array}{l}-0,70377^{*} \\
(-1,8223)\end{array}$ \\
\hline BK_MUT & $\begin{array}{l}-0,135931 \\
(-0,9762)\end{array}$ & $\begin{array}{l}-2,13809^{*} \\
(-1,8339) \\
\end{array}$ & $\begin{array}{l}-0,116321 \\
(-0,4852)\end{array}$ \\
\hline R-squared & 0,0525 & 0,283161 & 0,150708 \\
\hline adjusted R-squared & 0,0146 & 0,254487 & 0,116737 \\
\hline $\begin{array}{l}\text { Test of White for the } \\
\text { heteroscedasticity } \\
\text { null Assumption: } \\
\text { absence of } \\
\text { heteroscedasticity }\end{array}$ & $\begin{array}{l}\mathrm{TR}^{2}=5,06964 \\
\text { with p. value }=\mathrm{P} \\
(\text { Chi-square }(9) \quad> \\
5,06964)=0,828195\end{array}$ & $\begin{array}{l}\mathrm{TR}^{2}=11,6408 \\
\text { with p. value }=\mathrm{P} \\
(\text { Chi-square }(9) \quad> \\
11,6408)=0,234327\end{array}$ & $\begin{array}{l}\mathrm{TR}^{2}=15,4554 \\
\text { with p. value }=\mathrm{P} \\
\text { (Chi-square }(9) \quad> \\
15,4554)=0,079163\end{array}$ \\
\hline $\begin{array}{l}\text { Test of collinearity of } \\
\text { the variables (VIF) }\end{array}$ & $\begin{array}{l}\text { INFO 1,1 } \\
\text { BK_GRP 1,337 } \\
\text { BK_NAT 1,292 } \\
\text { BK_MUT } 1,239\end{array}$ & $\begin{array}{l}\text { INFO 1,1 } \\
\text { BK_GRP } 1,337 \\
\text { BK_NAT 1,292 } \\
\text { BK_MUT } 1,239\end{array}$ & $\begin{array}{l}\text { INFO 1,1 } \\
\text { BK_GRP 1,337 } \\
\text { BK_NAT 1,292 } \\
\text { BK_MUT } 1,239\end{array}$ \\
\hline
\end{tabular}

* Significant to $10 \%, * *$ significant to $5 \%, * * *$ significant to $1 \%$, (T of student). 


\section{$\underline{\text { TABLE 4: test of means difference }}$}

1st step: test of variance difference:

\begin{tabular}{|l|l|l|}
\hline Test of equality of the variances (F-Test) \\
\hline & $\begin{array}{l}\text { Short-term } \\
\text { credit }\end{array}$ & $\begin{array}{l}\text { Long-term } \\
\text { credit }\end{array}$ \\
\hline Mean & 62,5555556 & 70,222222 \\
\hline Variance & 1018,52778 & 695,694444 \\
\hline Observations & 9 & 9 \\
\hline Degree of freedom & 8 & 8 \\
\hline $\mathrm{f}$ & 1,46404472 & \\
\hline $\mathrm{P}(\mathrm{F}<\mathrm{f}$ ) one tail & 0,30116936 & \\
\hline $\mathrm{P}$. value for F one tail & 3,43810123 & \\
\hline & \multicolumn{2}{|l}{} \\
\hline
\end{tabular}

$\mathrm{F}(1,464)<\mathrm{f}$ one tail $(3,438)$

2nd stage: test of mean difference with equal variance

\begin{tabular}{|l|l|l|}
\hline $\begin{array}{l}\text { Test of the expected value equality: two observations of equal } \\
\text { variances }\end{array}$ & & \\
\hline & $\begin{array}{l}\text { Short-term } \\
\text { credit }\end{array}$ & $\begin{array}{l}\text { Long-term } \\
\text { credit }\end{array}$ \\
\hline Mean & 62,5555556 & 70,2222222 \\
\hline Variance & 1018,52778 & 695,694444 \\
\hline Observations & 9 & 9 \\
\hline Pooled variance & 857,111111 & \\
\hline Hypothesized Mean Difference & 0 & \\
\hline Degree of freedom & 16 & \\
\hline Statistics t & $-0,55551306$ & \\
\hline P $($ T<=t) one tail & 0,293114 & \\
\hline T Critical one tail & 1,74588367 & \\
\hline P $($ T<=t) two tail & 0,586228 & \\
\hline T Critical two tail & 2,11990529 & \\
\hline
\end{tabular}

T one tail $(0,2931)<\mathrm{t}$ critical one tail $(1,745)$ 